\title{
The shark by-catch of tuna longline fisheries in Southern Indian Ocean of Java, Indonesia
}

\author{
Priyo Suharsono Sulaiman ${ }^{1, *}$, Mufti Petala Patria ${ }^{2}$, and Rauf Achmad Sue ${ }^{3}$ \\ ${ }^{1}$ School of Environmental Science, Universitas Indonesia, Indonesia \\ ${ }^{2}$ Department of Biology, Faculty of Mathematics and Natural Sciences, Universitas Indonesia, \\ Indonesia \\ ${ }^{3}$ Fisheries University of Jakarta, Pasar Minggu Jakarta, Indonesia
}

\begin{abstract}
In relation to the achievement of the target SDG's No. 14, the sustainable shark fisheries management need to implement. As a part of the tuna fisheries by-catch, a high number of shark resources have been caught in the Indian Ocean waters. One of the main vessels of tuna catchers in the Southern Indian Ocean of Java is the tuna longline from Cilacap. This paper aims to analyze the shark by-catch of tuna longline in the Indian Ocean in the south Java that landed in Cilacap. The research data was obtained from daily recording activities of fishing vessel loading activities by Cilacap Ocean Fisheries Port staff during the period of 2013-2017. The analysis was done through data tabulation, graphical approaches, and data trend analysis through the availability of time series data. The data analyzed include fleet development, fishing ground, catch composition and CPUE value. The results of the analysis show that there are about eight species of sharks that are by-catch of tuna longline from Cilacap. The highest shark by-catch occurred in April with CPUE averaging 9 $\mathrm{kg} /$ day/vessel. The blue shark (Prionace glauca) is the dominant shark catch which reaches $66 \%$ of the total sharks catch.
\end{abstract}

\section{Introduction}

Cilacap Ocean Fisheries Port (OFP) is the largest fishing port on the south coast of Java Island. Based on Cilacap OFP fisheries statistics, tuna longline is one of the dominant fishing gears used to catch tuna in the Indian Ocean. A total of 188 tuna longline fishing vessel were recorded based on this port with a total catch of various species of fish reaching $3,178.75$ tons in 2016 [1].

In each activity of catching tuna as a target, other marine biotas are also caught namely by-catch. As part of tuna fishing by-catch, sharks are one of the main predators in the food chain in marine waters. Shark mortality rates are very high due to accidental catches by fishermen, and it is not uncommon the sharks catch are being thrown back into the sea [2]. In Indonesia, most shark fishery products are by-products $(72 \%)$, and $28 \%$ are produced as a result of major catches [3].

\footnotetext{
${ }^{*}$ Corresponding author: priyo.sulaiman@gmail.com
} 
Shark fish resources that have been caught in Indonesia's marine waters, including in the Indian Ocean, are very high. It was noted that as many as 1000 tons of sharks of various species were captured from various Indonesian marine waters in 1950 and continued to increase to 95,600 tons in 1997 [4]. Based on Cilacap OFP statistics, there were 533.41 tons of sharks caught in the Indian Ocean and landed in Cilacap with a value of almost IDR 7 billion in 2016 [1].

In relation to the achievement of the target sustainable development goals (SDG's) No. 14, namely conserve and sustainably use the oceans, seas and marine resources for sustainable development, the sustainable fisheries management need to implement. One of them is the shark fisheries management in the Indian Ocean of Indonesia. The shark fisheries management is implemented in order to achieve long-term catching fish, maintain an ecosystem balance, and maintain biological, social and economic systems [5].

The scientific study of the shark resource stocks in the Indian Ocean is uncertain [6] and still need to continue observing. Nevertheless, the utilization status of large pelagic fish resources in the Indian Ocean (sharks fall into this category) has reached over-fishing conditions [7], whereas to ensure its sustainability, the highest utilization status that permitted is in fully exploited level. In order to overcome these problems, a precautionary approach management can be undertaken.

At present, research on the shark fish resources as by-catch by tuna fishermen in the Indian Ocean continues to be carried out and developed and updated. This is important because the information can be used as a scientific basis for the shark fisheries management in the Indian Ocean. This paper aims to examine the shark by-catch of tuna longline in the Indian Ocean in the south Java that landed in Cilacap.

\section{Materials and method}

The study was conducted at the main shark landing site in the south of Java, the Cilacap OFP. The research data was obtained from enumeration activities/daily recording of unloading activity of tuna longline vessels by officers of the Cilacap OFP during the period of 2013-2017. The data includes information about tuna longline vessel catches per tip, catch composition, fishing ground, and fishing trip duration. The collected data is then analyzed descriptively using Microsoft Excel in the form of data tabulation, graphical approaches, and data trend analysis through the availability of time series data. The catch per unit effort (CPUE) value, was calculated by the following formula [8]:

$$
\text { CPUE }_{i}=\frac{\text { catch }_{i}}{\text { effort }_{i}}
$$

where $C P U E_{i} \quad$ is catch per unit effort (Kg/unit) in trip i, catch $h_{i}$ is a quantity of catch fish $(\mathrm{kg})$ in month $\mathrm{i}$, and effort $_{i}$ is catch effort (each vessel) in trip $\mathrm{i}$.

\section{Results and discussion}

\subsection{Shark fishing vessel and the fishing ground}

Many shark resources are captured as by-catch using tuna longline fishing gear, drifting gill nets, bottom set gill nets, and become the target by shark longline. Sharks fishing activities in these waters have been going on for a long time. The existence of an opportunity for economical utilization and the absence of regulations that prohibit it, resulting in the development of shark landing centers which are caught by fishermen on the west coast of 
Sumatra, south of Java (Cilacap) to Nusa Tenggara. The development of the number of shark fishing fleets operating in the Indian Ocean and originating from Cilacap can be seen in Table 1 .

Table 1. Development of sharks catch fleet originating from Cilacap.

\begin{tabular}{|l|r|r|r|r|r|r|r|r|}
\hline \multirow{2}{*}{ Type of Fishing Gear } & \multicolumn{8}{|c|}{ Year } \\
\cline { 2 - 8 } & $\mathbf{2 0 1 0}$ & $\mathbf{2 0 1 1}$ & $\mathbf{2 0 1 2}$ & $\mathbf{2 0 1 3}$ & $\mathbf{2 0 1 4}$ & $\mathbf{2 0 1 5}$ & $\mathbf{2 0 1 6}$ & $\mathbf{2 0 1 7}$ \\
\hline Tuna longline & 245 & 299 & 265 & 243 & 198 & 198 & 188 & 173 \\
Shark longline & - & - & - & 11 & 16 & 16 & - & 1 \\
Drift gills nets & 165 & 205 & 202 & 230 & 127 & 127 & 127 & 122 \\
Bottom set gills nets & 11 & 18 & 12 & 7 & - & - & - & - \\
\hline
\end{tabular}

Based on Table 1 it can be seen that the tuna longline vessel is the dominant fishing fleet operated by fishermen from Cilacap in the Indian Ocean. The development of the use of this fishing gear is very natural because the Indian Ocean has a high potential of tuna fish resources with high economic value. In tuna fishing activities using tuna longline, sharks are caught as a by-catch. The location of shark fishing in the Indian Ocean by fishing vessels originating from Cilacap generally leads to the south, but sometimes it is also found a tuna longline fishing vessel fleet that catches fish to the west until it reaches West Sumatra Indian Ocean. More specifically, shark fishing areas in the Indian Ocean using tuna longline can be seen in Figure 1.

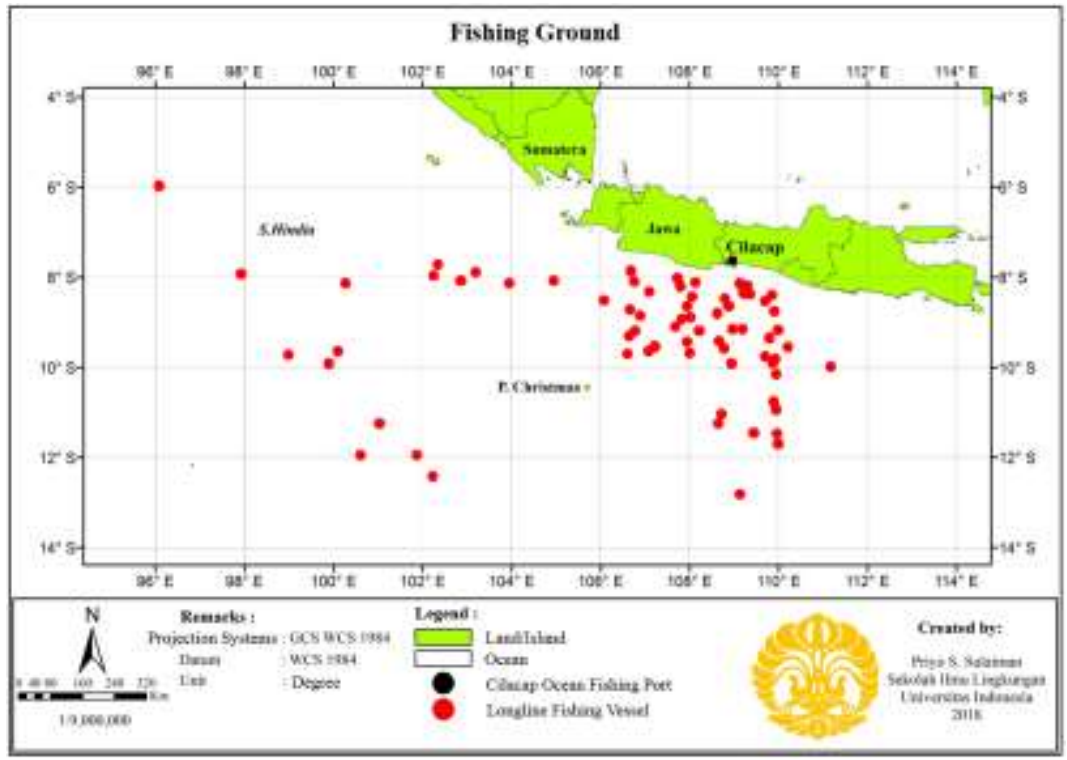

Fig. 1. Fishing ground for tuna longline fishing vessel.

\subsection{By-catch and composition of sharks catches}

In tuna fishing activities, various by-catch biotas are often caught. This biota was caught because it has ecological linkages with the living habitat of tuna. Several species of bycatch biota in the tuna longline fishing can be seen in Table 2 . 
Table 2. By-catch types of tuna longline fishing.

\begin{tabular}{|l|l|l|c|}
\hline Fishing Gear & \multicolumn{1}{|c|}{ Main Target } & \multicolumn{1}{|c|}{ By-catch Species } & $\begin{array}{c}\text { \% Shark } \\
\text { By-catch }\end{array}$ \\
\hline Tuna longline & $\begin{array}{l}\text { Yellowfin tuna, } \\
\text { Bigeye tuna }\end{array}$ & $\begin{array}{l}\text { billfish, shark, stingray, gindara, } \\
\text { mahi-mahi, opah, spanish mackerel, } \\
\text { skipjack, pick-handle barracuda, etc. }\end{array}$ & 8,80 \\
\hline
\end{tabular}

By-catch longline tuna fisheries are generally organisms that can be utilized economically. Based on the analysis of tuna longline catch landed in Cilacap during 20132017 , it is known that the by-catch volume of sharks reaches $8.5 \%$ of the total by-catch of the tuna longline fleet there. The by-catch percentage can differ on each fishing boat. This is very much influenced by the season, the location of the catch and the fishing techniques used. The composition of the number and type of target fish species and by-catch of tuna longline are also strongly influenced by the gear configuration, especially the position of the fishing line in the water (the depth of hooks), when and where to catch related habitat, the spread and life habits of fish species [9]. The catch of medium type tuna fishing rods obtained target fish of $26.31 \%$, fish by-catch of $16.72 \%$. Deep type tuna longline catches, obtained the fish target of $25.62 \%$, and by-catch as much as $42.15 \%$ [10].

The results of the analysis on the tuna longline fishing gear showed that the most caught was the blue shark (Prionance glauca) reached $66 \%$ of the total shark catch, followed by the whaler shark (Carcharhinus sp.) of $12.7 \%$ and the big-eye thresher (Alopias superlicious) of $8.9 \%$ (Figure 2). This finding is in line with [11] who said that the types of sharks that often become by-catch in the longline tuna fisheries are blue sharks, oceanic white-tip shark, pelagic thresher shark (Alopias pelagicus), and short-fin mako shark (Isurus oxyrhyncus).

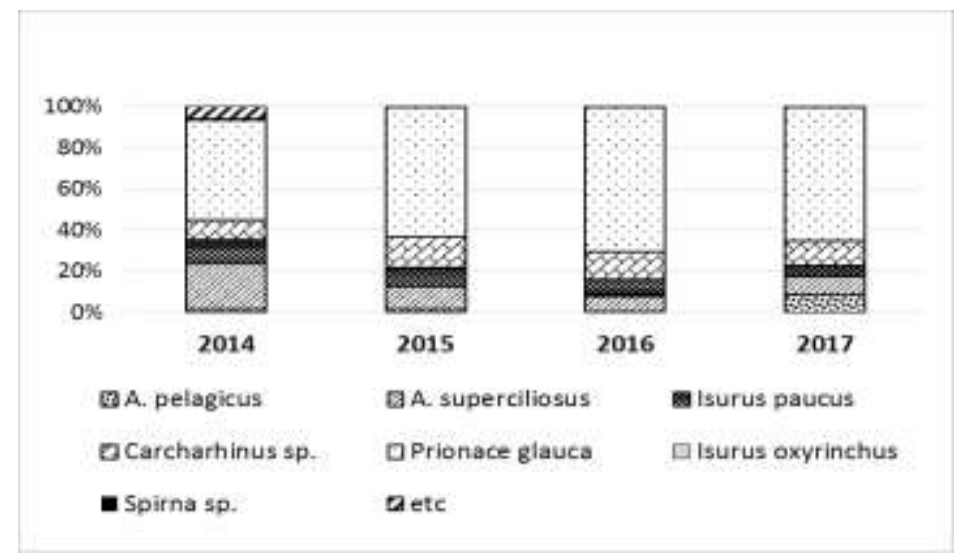

Fig. 2. The composition of shark by-catch caught by tuna longline vessel.

Similar results were also obtained by [12] in a trial of tuna longline in Japanese waters with a dominant catch of blue sharks (more than $90 \%$ of the total catch of sharks), and [13] in the North Atlantic waters with catches of blue sharks reaching $52 \%$ of the total fish catch. Different results were reported by [14] with grey reef shark as the dominant catch reaching $89.9 \%$, and [15] with whaler sharks reaching $50 \%$ of the total catch in Indian marine waters.

The capture of blue sharks in the Indian Ocean, allegedly due to a fairly strong association between habitat and food of tuna fish as target fish, with sharks caught as bycatch, because blue sharks are oceanic sharks. This is consistent with [16] which states that 
blue sharks are oceanic and pelagic biota that live on the surface layer to a depth of 600-800 $\mathrm{m}$, and are able to migrate over long distances. This species is sometimes caught by tuna longline, sharks longline, and tuna gill nets.

\subsection{Catch per unit effort (CPUE)}

CPUE can be used as an indicator of the level of technical efficiency of the capture effort. The calculation of the catch, the number of attempts, and CPUE are based on the daily loading data of the vessel at Cilacap OFP during the period 2013-2017. For more details, the results of calculating the CPUE value of the tuna longline fishing vessel in catching sharks are seen in Figure 3.

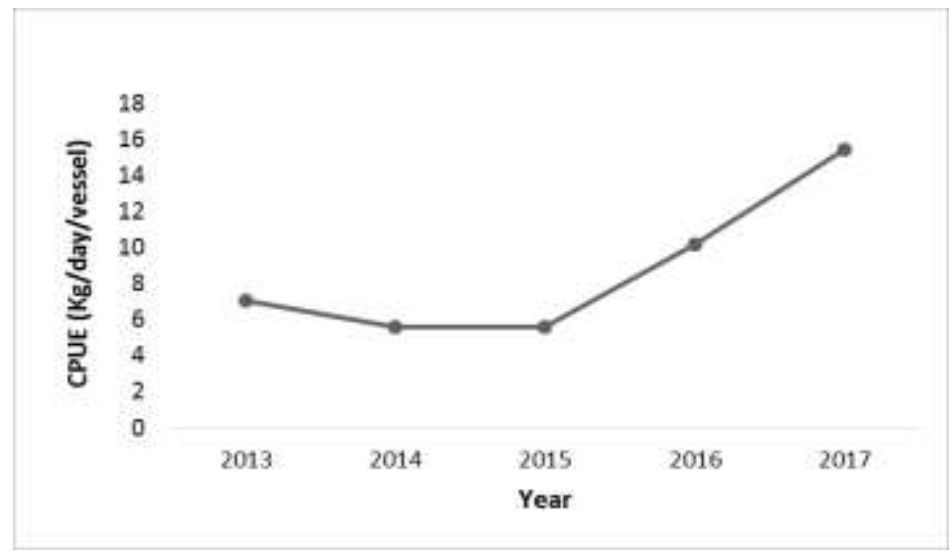

Fig. 3. CPUE of tuna longline fleet in catching sharks.

Based on Figure 2 it can be seen that there is a tendency of increased CPUE values during the period 2013-2017 with the lowest values occurring in 2014 and 2015 of 6 $\mathrm{kg} /$ day/vessel and the highest in 2017 of $15 \mathrm{~kg} /$ day/vessel. The trend of an increase in CPUE values is inversely proportional to [17] research in Indian EEZ waters which shows a decline in sharks CPUE. The data used in the analysis of [17] is the 1984-2006 data as for the data used in this research is from 2013-2017. One of the alleged causes of differences in the trend of CPUE values is related to differences in the use of supporting technology in fishing operations. The trend of increasing the value of CPUE shark catchers from Cilacap can be an indicator that the technical efficiency of shark fishing activities is increasing from year to year. The use of supporting technology in fishing activities is thought to have an effect on the ability of fishermen to catch fish, including also affecting the length and distance of fishing trips that are farther away, without worrying about the potential for a decline in the quality of fish caught. The increase in fishing duration can have an impact on the increase in fish caught by fishermen.

Monthly CPUE analysis of shark catches in tuna longline fleet in the Indian Ocean can be seen in Figure 4. Analyst results show that the CPUE values generated fluctuate greatly in each month, but in January each CPUE value is consistently low and in April the production value is consistently high. 


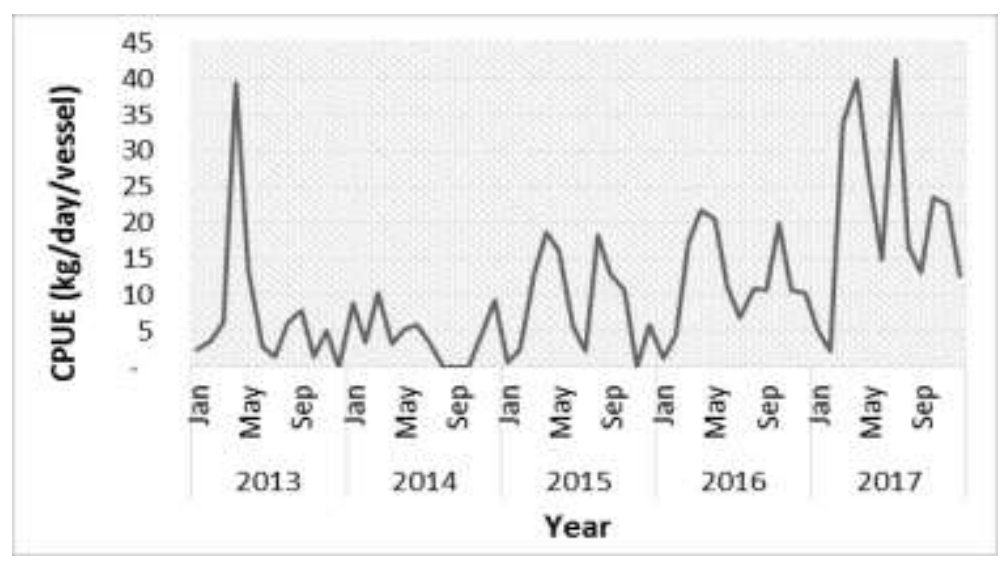

Fig. 4. Monthly CPUE of sharks catches of tuna longline fishing.

Based on the calculation results, it is known that the highest CPUE value occurred in July 2017 which reached $43 \mathrm{~kg} /$ day /ship. This finding is slightly different from [18] which states that in hand-line fishing in the waters of the Indian Ocean south of Bali, the peak of by-catch fishing occurs in August-October. This difference in results is thought to be related to differences in fishing gear and differences in fishing locations, where the tuna longline fleet from Cilacap conducts more fishing operations in the southern waters of Central Java with a tendency to move westward as shown in Figure 1.

CPUE values obtained in February 2017 amounted to $2.6 \mathrm{~kg} /$ day/vessel. Not only in February 2017, in January of the previous years $(2013,2014,2015,2016)$ the CPUE value of the shark fishing fleet in the Indian Ocean from Cilacap was always the lowest compared to other months. The low CPUE value of the fishermen's catch is thought to be related to the existence of the west monsoon which blows between October and February which causes high waves in the sea. At the time of monsoon, the highest peak of the highest waves occurred in January and July [19]. High waves will make it difficult for fishermen to catch fish in the sea. In cases of extreme tidal waves, even a fleet of fishing boats must lean back on the beach to avoid the danger of shipwrecks being hit by waves.

\section{Conclusion}

There are about eight species of sharks that are by-catch of longline tuna fishing from Cilacap, with the blue shark being the dominant shark catch which reaches $66 \%$ of the total shark catch. The CPUE value of shark by-catch during the 2013-2014 periods tends to increase with the highest average value occurring in April of $25 \mathrm{~kg} / \mathrm{day} / \mathrm{vessel}$.

\section{References}

1. DGCF, Capture Fisheries Statistic of Cilacap Ocean Fisheries Port (Directorate General of Capture Fisheries, Ministry of Marine Affairs and Fisheries, 2017)

2. M. Camhi, S. Fowler, J. Musick, A. Brautugam, S. Fordham, Sharks and their relatives, ecology, and conservation (IUCN, UK, 1998)

3. I.M. Zainudin, Ecosystem-based shark fisheries management in Indonesia. Major Thesis. Department of Biology, Faculty of Mathematics and Natural Sciences, Universitas Indonesia (in Bahasa) (2011) 
4. FAO, FAO Global Capture Production database updated to 2015. Summary information: Fisheries and Aquaculture Department (Food and Agriculture Organization of the United Nations, Rome, 2015)

5. R. Hilborn, Are sustainable fisheries achievable? Marine conservation biology: the science of maintaining the sea's biodiversity (Island Press, Washington, 2005)

6. IOTC, http://www.iotc.org/science/status-summary-species-tuna-and-tuna-speciesunder-iotc-mandate-well-other-species-impacted-iotc (2016)

7. Regulation of the Minister of Marine Affairs and Fisheries 47/KEPMEN-KP/2016, About estimation of potential, a number of accounts allowed, and level of utilization of fish resources in the regional management of state fisheries of the Republic of Indonesia (Ministry of Marine Affairs and Fisheries, 2016)

8. J.A. Gulland, Manual of methods for fish stock assessment part I (FAO, Rome, 1982)

9. P.K. Bartram, J.J. Kaneko, Catch to By-catch Ratios: Comparing Hawaii's Longline Fisheries with Others (The University of Hawaii-NOAA, Joint Institute for Marine and Atmospheric Research, 2009)

10. D. Novianto, B. Nugraha, Marine Fisheries 5, 2, 119-127 (2014)

11. A.A. Widodo, B.I. Prisantoso, R.T. Mahulette,s The species and size distribution of fish by-catch in tuna fisheries in the Pacific Ocean (National Research Council Ministry of Research and Technology- Agency of Maritime and Fisheries Research, Jakarta, 2010)

12. K.Yokota, M. Kiyota, H. Minami, Fisheries Research 81, 2-3, 337-341 (2006)

13. J. W. Watson, S. P. Epperly, A. K. Shah, D.G. Foster, Canadian Journal of Fisheries and Aquatic Sciences 62, 5, 965-981 (2005)

14. K. Kumar, P. Pravin, B. Meenakumari, P. Khanolkar, M. Baiju, Journal of Applied Ichthyology, 31, 2, 301-307 (2015)

15. S.P. Varghese, K. Vijayakumaran, A. Tiburtius, V.D. Mhatre, Indian Journal of Geomarine Science. 44, 1, 26-36 (2015)

16. W.T. White, P.R. Last, J.D. Stevens, G.K. Yearsley, Fahmi, Dharmadi. Economically important sharks \& rays of Indonesia (Australian Centre for International Agricultural Research, 2006)

17. M. John, B. Varghese, Decline in CPUE of oceanic sharks in the Indian EEZ: urgent need for precautionary approach. Paper presented at IOTC Working Party on Ecosystems and Bycatch. Mombasa, Kenya (2009)

18. R.K. Sulistyaningsih, A. Barata, K. Siregar, Indonesian Fisheries Research Journal, 17, 3, 185-191 (2011)

19. R. Kurniawan, M.N. Habibie, Journal of Meteorology dan Geophysics 12, 3, (2011) 